\title{
1. Dancing without listening to the music: learning from some failures of the 'national innovation systems' in Latin America ${ }^{1}$
}

Pierre Delvenne and François Thoreau

\section{INTRODUCTION}

Over the last three decades, the field of 'innovation studies' has taken shape and expanded significantly (Fagerberg and Verspagen 2009). Part of this has been the approach of national innovation systems (NISs) (Freeman 1987 for a first occurrence; Lundvall 1992; Nelson 1993; Kuhlmann 2001), which was formulated in the early 1990s and has reached an ever-growing audience since then. This approach is rooted in the works of the nineteenth-century German economist Friedrich List, who authored The National System of Political Economy in 1841 (Freeman 1995, p.5). It is also greatly indebted to the eclectic thoughts of Joseph Schumpeter, an economist who laid the groundwork for evolutionary approaches to economy. It helps in understanding the systemic conditions of innovation so as to promote it further.

While there are different definitions of $\mathrm{NISs}^{2}$ (cf. Niosi 2002), the definition from Edquist and Lundvall (1993) is pertinent because it also shows the far-reaching ambition sustained by the approach: the national system of innovation is constituted by the institutions and economic structures affecting the rate and direction of technological change in society. While NISs approaches can be limited to mapping institutions and structures, there is a commitment about 'change' that raises the question of how societies change, especially when linked to innovation (either technological or social). Thus, the abundant literature on NISs is about the idea that a set of interdependent actors and institutions need to be aligned together so as to initiate dynamics of technological and economic change. It goes far beyond a limited focus on research and development (R\&D) and companies only (Freeman 1995, p.9), because it also opens up questions about 
ongoing societal change. Lundvall, in an attempt to disclose the political agenda of NISs, refers to it as a 'critical social engineering with theoretical ambitions' (2005, p.4). This makes NISs an important topic for science, technology and innovation policy (STIP) studies and to address the broader questions like their adequacy to handle the most pressing needs of the developing countries (see for example the Lundvall et al. 2009 Handbook of Innovation Systems and Developing Countries ${ }^{3}$ ), such as solving poverty, reducing social inequalities and exclusion, increasing productivity and creating jobs.

Over the last 20 years, NISs approaches have gained a lot of attention and consideration both inside and outside academia (Sharif 2006; Fagerberg and Sapprasert 2011). They have been very influential in national policy circles as well as global policy arenas. Many organizations are today using the concepts developed in NISs literature. It should be noted that both the Organisation for Economic Co-operation and Development (OECD) and the United Nations Educational, Scientific and Cultural Organization (UNESCO) have developed national 'systems'-level mapping and review approaches since the 1960s (cf. also Godin 2009). NISs consist in an approach rather than a theory. However, calls have been voiced to systematize the approach using formal criteria, drawn from empirical data, so as to turn the approach into something 'theory-like' (Edquist 2004b, p.486). There have also been some empirical studies of the approach's use. In an extensive ethnographic study, Albert and Laberge (2007) show the ways in which NISs are taken up in public administrations, including the narrowing down that occurs. This is also our starting point: the different reductions that we see occurring with, and through, the NISs' 'theory-like approach', potentially leading to an unproductive reification, whereas 'creative destruction' should prevail, according to Kuhlmann et al., attempting to renew a systemic Schumpeterian tradition (2010, p.2).

As Wallerstein (2004, p. 83) notes,

the term 'theory' tends to evoke for most people the concept of a set of interconnected ideas that are coherent, rigorous and clear, and from which may derive explanations of empirical reality. The term also denotes, however, the end of a process of generalization and therefore a closure, even if provisional.

In this chapter, we observe that in Latin American countries the theoretical power of NISs in the construction of seemingly 
adequate and plausible explanations of complex innovation phenomena imposed premature closure on scientific and policy activity, and therefore was to some extent counterproductive.

Kuhlmann et al. (2010) state that innovation is a complex process for which a systemic approach is required. This demands that one pays attention to two specific triangulations, a first one that binds together practice, policy and theory, and another one that demands to take into account social, economic and technological parameters. We argue that in this respect most actual NISs approaches lack a reflection upon 'practice' (hence favouring policy and theory), while also neglecting the 'social' dimension (henceforth focusing on economic and technological ones). This book is based on a systemic perspective of the 'innovation policy dance' metaphor, meaning that innovation theory, policy and practice interact - they 'dance' together and, by moving on the 'dance floor', they learn from each other and finally contribute together to changing perspectives and prevailing modes of guidance (Kuhlmann et al. 2010, pp.7-8).

Our chapter pursues the 'dancing partners' metaphor (Rip 1992; Kuhlmann 2007) and, building on our previous work (i.e. Delvenne and Thoreau 2012), we aim at developing a critical perspective on NISs that transcends its focus on the 'charmed circle' of OECD countries (see also Delvenne and Vasen 2013). In some developing countries, NISs and innovation theory have been driving forces that bumped into other dancers, that is, innovation practice and innovation policy. We profit from an abundant body of scholarly work from Latin American authors who deal with innovation systems - but which has been overlooked in the NISs literature - to argue that what sometimes happens in the innovation policy dance is dancing without paying attention to the surrounding music. The implication is that NISs approaches should integrate more complexity and diversity, through a variety of complementary analytical perspectives: post-colonial theory, world-system analysis and, when relevant, considering an approach which may overcome the 'developmentality' paradigm. Our overview of the historical trajectory of the science, technology and innovation (STI) regimes in Latin America shows its importance, and we offer some concrete approaches to carry it forward. ${ }^{4}$ 


\section{NATIONAL INNOVATION SYSTEMS AND THE CRITIQUE OF THEIR REIFICATION}

Most STIP studies are carried out for the USA, the EU and Japan (the 'Triad'), and international competitiveness, an important concern of these studies, is analysed as occurring between Triad countries - although this is changing now with the rise of China, India and Brazil on the global scene. STIP studies do not take into account the full texture of interesting developments that are taking place in Asian, African and Latin American countries. NISs approaches are applied more widely, as in the Global Network for Economics of Learning, Innovation, and Competence Building Systems (Globelics), launched in 2002 under the aegis of Lundvall and Soete, with the laudable objective of "creating a global network of scholars who apply the concept "systems of innovation and competence building" as their analytical framework' (2002). In the annual Globelics conferences, there are many papers about developing countries, but the emphasis is often on simplified mapping and diagnosis of national systems. The aim is more ambitious, however: 'There is in our view a crucial need to broaden this framework not just geographically but also content-wise to incorporate the rapid rise in globalization pressures and the corresponding weakness of global governance mechanisms' (Lundvall and Soete 2002).

This goes with an explicit normative commitment to improve development dynamics in countries of the global South. They insist that NISs have a greater marginal utility in developing, rather than developed, countries. There is a commitment to "promoting development in those parts of the world where a large proportion of the population lives in poverty' (Lundvall et al. 2009, p.1). In practice, this commitment is often taken up with the idea of 'closing the gap' between poor and rich countries by expanding poorer countries' gross domestic products (GDPs) and, generally, the 'catching-up' approach favoured by the so-called Washington Consensus, which Lundvall et al. aim at overcoming (Metcalfe and Ramlogan 2008). It is true that NISs helped to move beyond the neoliberal ideas of the Washington Consensus that strive towards increasing international competitiveness, a diminished role of the state, lowered wages and currency devaluations (Lundvall 2005, p.6).

While the NISs framework of analysis, building on what was happening already, has proved to be helpful for the design and 
evaluation of STI policies in the OECD's industrialized economies (and thus was a productive reduction of complexity), the ex-ante promotion of NISs in Latin America implied a normative agenda of what had to happen (Arocena and Sutz 2000), with OECD countries as a model, which was not adequate for representing actual complexities. ${ }^{5}$ As Vasen (2011) indicates when discussing Latin America,

the very low demand for scientific knowledge from the side of the productive sector, the predominance of state-driven basic research on industrialdriven applied research, the scarce investments of national industries in $R \& D$ as well as the profile of higher education institutions, more inclined to train professionals rather than supporting scientific research, lead to a configuration where NISs are not likely to emerge naturally. (Vasen 2011, p.18, our translation)

A die-hard NISs advocate will argue that this situation only shows that implementation of NISs is needed, but this is more a matter of conviction than of evidence that it will actually be helpful (and helpful for what?). We want to pursue another 'conviction', that the present NISs approach is not a one-sizefits-all solution for Southern countries. A fit with already existing regimes and traditions of science and technology policies is necessary, and this requires broadening the approach and rendering it more complex. To put it differently, coming back to the innovation policy dance (Kuhlmann et al. 2010, pp.7-8) metaphor underlined previously, dancing with systemic approaches to innovation without paying attention to the contextual music reveals too much normative reification of such approaches.

The normative reification of NISs that is visible (also within Latin American countries) operates a threefold reduction of complexity that reduces the productivity of the approach and, more importantly, induces blind spots likely to impair the understanding of the nature, pace and direction of the process of technological change of those economies. Therefore, it also affects the identification of their determinants, and thus induces inappropriate policy prescriptions. ${ }^{6}$

First, for both OECD- and non-OECD-centric studies, NISs approaches are not permeated enough by the broader sociopolitical landscape and the global context (historical perspectives, social and geopolitical issues, entanglement of modernities). In particular, NISs do not pay sufficient attention to the regimes of science and innovation, which are important in understanding 
long-term dynamics, possibilities and constraints because they emphasize histories and path dependencies (Garud and Karnoe 2010). Regimes consist of institutions, rules and arrangements that shape ongoing science and innovation. The regimes are themselves shaped by explicit governance (i.e. STI policies), and they evolve according to specific institutional constraints, social orders and cultural norms. Regimes also respond to broader changes, like reflexive modernization (see Delvenne 2011). Influential authors in the field appear to recognize this, such as when Freeman argues for taking into account the organizational embeddedness in a much wider socio-economic system in which political and cultural influences as well as economic policies help to determine the scale, direction and relative success of all innovative activities' (2002, p.195). Despite such repeated claims (Edquist 2004a; in the case of development Lundvall et al. 2009, p.3) that such elements are being taken into account, we find that those are often backgrounded or reduced to simplistic dichotomies (e.g. modern/traditional, nature/culture, First World/Third World, developed/underdeveloped).

Second, in addition to a usually too narrow geographical focus, the wide circulation of NISs beyond OECD member countries reproduces the balance of power between richer and poorer countries, even while it pursues the objective of socioeconomic development (for instance through the Washington Consensus). As Bruno (2009) demonstrated, there is a 'neoliberal commitment' which pervades the international benchmarking of economic performances among countries or regions, neglecting how many more vectors of international inequality lie out there.

Third, NISs approaches advocate (technological) change in society but strongly orientate the directionality towards GDP generation and the pursuit of economic growth. These macroeconomic goals constitute the dominant icons of a 'catching-up modernism' where there are no other specific targets than advancing 'progress' and stimulating economic benefits.

Evidence from empirical studies, for instance Nassif (2007), who makes a comparative analysis of Brazil and India's economic performances, shows that a country's performance is also explained by its institutional capacity for coordinating conventional macroeconomic policies with other policies related to its NISs. ${ }^{7}$ Even in Brazil's most competitive industries, like the biotechnology sector, broader cultural aspects like the researchers' 
aversion to business affect the efficiency of the NISs in that sector (Marques and Gonçalves 2007).

In the next section we provide an overview of Latin American developments and the trajectories of their STI regimes. We start our account in the 1950s and show that, despite some social and academic resistance in Southern countries, Northern institutional models of science organization and funding were duplicated, with the help of certain international institutions, like UNESCO or the Organization of American States (OAS), and local scientific communities. We then continue until the late 1990s, when NISs were introduced in Latin American countries. Our reference to relevant contextual elements will allow us to unfold our reification critique of NISs.

\section{BREAKING THE OECD ‘CHARMED CIRCLE’ IN LATIN AMERICA $^{8}$}

This section examines the trajectory of Latin American STI regimes (Delvenne and Thoreau 2012). There are the global and regional contexts, for instance the emergence of the US hegemonic power and the rise of the Third World's (geo)political claims, the impacts of the broad debates of dependency theory, the aftermath of the 1959 Cuban revolution and the rise of a Latin American movement for science, technology and development in the 1960s. We will not present a full historical reconstruction here, but it informs our discussion of the limitations of NISs studies, and how contextual elements got aligned and a lock-in occurred with NISs approaches. This point is of practical importance, not just a dispute about a concept. NISs embed a well-routinized script with regard to the future of countries, which may not be adequate to address the pressing STI-related issues in these countries. For example, the actual trade pattern, in Metcalfe and Ramlogan's words (2008, p.434), 'works to reduce local innovation capacity and risks locking Latin America into increasingly unfavourable terms of trade and out of rapid growth markets based on the exploitation of different technological trajectories; [it sounds as though] a modern north/south echo of the [dependency theory] thesis [is in order]'. Thus, the spell of NISs should be broken, and changes and challenges considered in their own right. ${ }^{9}$

Regarding Latin America, more than for OECD countries, 
the social and the geopolitical dimensions are explicit and predominant. The social dimension is prioritized because of the high level of poverty and the broad social inequality in Latin American societies (Sutz 2003). The (geo)political dimension is highly noticeable because STI issues are related to broad North/South geopolitical issues like the exploitation of natural resources, the lack of scientific and technological autonomy, the transfer and implementation of risky technologies, disputes over intellectual property, political instability and the influence of international institutions over the design of public policies. Even when the priorities in Latin American STI policies have aimed at contributing to socio-economic development, the scientific community seems to have been more interested in following international scientific trends rather than focusing on local realities and needs (Pellegrini 2011; Vasen 2011). This might be changing now; in any case, the discussion about relevance is now quite explicit.

In the 1950s, various research agencies were created in Latin America (INIC/CONACYT in Mexico, CNPq in Brazil, CONICET in Argentina), according to the model of a pure science based on academic excellence. The rationale was that, in order to develop scientific and technological applications likely to create growth and social welfare, one had to start with sponsoring basic research, with little or no political interference. This model was promoted by the alliance of UNESCO (in particular, the Regional Bureau for Sciences in Latin America and the Caribbean, based in Montevideo), the OAS and local scientific communities. Albornoz and Gordon (2011) consider that both UNESCO and OAS played a key role in the diffusion of ideas and concepts in Latin America, one that would be comparable with the role of the OECD in industrialized Western countries. ${ }^{10}$

Later on, a number of explicit or implicit science and technology policies were established. In the wake of the Cuban revolution of 1959, Latin American societies went through a phase of radicalization that also reached academia and the scientific community. Debates about the relevance of science for national prestige or bellicose patriotism were eclipsed by a political revolutionary turn in Latin America, stressing the colonial components of an externally defined science organization (Vasen 2011). Herrera (1971) was arguing against the gap between the international research agendas and the local needs in Latin America, while Sábato (2004 [1979]) - who was more preoccupied by the needs of the industrial sector - wanted to create spaces of 
knowledge transfer between the public and private sectors, especially in metallurgy. Varsafsky (1972) had a more radical approach in denouncing the ideological character of the mode of scientific knowledge production, as he wanted to develop a new type of science that would help achieve a socialist revolution.

Dependency theory arose as a reaction to modernization and development theories. ${ }^{11}$ The latter held that all societies progress through similar stages of development. Dependency theory argues that underdeveloped countries are not merely primitive versions of developed countries, but have unique features and structures of their own. Their heritage of being former colonies, whose economies were built primarily to serve the interests of Northern countries, would be one cause of their dependent position in the global economy. One strategy for less developed countries would then be to go against dependency by reducing their connectedness with the world market.

The wave of dictatorships that were installed almost everywhere in Latin America from the 1970s until the mid-1980s significantly weakened the phase of radicalization of cultural and academic claims on the domination of Northern countries, while at the same time it led many Latin American scientists and technologists into exile (Roninger et al. 2012). With the exception of Brazil, where the dictatorship was supportive of industry, most Latin American countries went through a time of deindustrialization and openings of their economies.

When Latin American states returned to democracy in the second half of the 1980s, 'there was no alternative' powerful enough to counter the already running movement of deindustrialization and globalization of economic markets. Also, the dismantlement of the USSR at the end of the Cold War, together with the illusion of the US remaining the sole superpower and, in particular, the rise of the Washington Consensus, contributed to the endorsement of neoliberal STI policies in Latin America. From the mid-1990s, with the support of the Inter-American Development Bank (IDB), national systems of innovation were introduced (Melo 2001), and a set of indicators related to science and technology was developed - the Red Iberoamericana de Indicadores de Ciencia y Tecnología (RICYT). ${ }^{12}$ This does not mean that it happened without academic resistance to the coming era of such 'pre-packaged thinking' models (Shinn 2002). But the 'anti-mimetic movement' (Albornoz and Gordon 2011) could not stop the institutional mimesis, that is, in this case, of 
NISs. In fact, critical reflection on the relevance of NISs-inspired politics, when it occurred, tended to criticize mere duplication but not the concept of NISs itself (Arocena and Sutz 2000, 2003). A number of scholars (e.g. Lastres and Cassiolato 2002; Metcalfe and Ramlogan 2008), when they look at the recent restructuration of Latin American economies to exploit resource-based comparative advantage (pulp and paper, soybean, steel) and at their actual organization on a low-skill, non-engineering model controlled by foreign enterprises, stress that NISs in Latin America remain rather weak and unarticulated, with rare local innovation capacities. Like Arocena and Sutz (2003) they advocate the '[creation of] a Southern framework of thought that could benefit from incorporating some of the premises of the Latin American underdevelopment theory' (Lastres and Cassiolato 2002, p.5). Still, Lastres and Cassiolato, like many others and in spite of good intentions of 'developing new conceptual, methodological and analytical frameworks to deal with the new pattern' $(2002$, p.6), fall back on stressing the 'usefulness of the concept of (national) system of innovation' (2002, pp.6-7).

This creates a paradoxical situation, where scholars stress the pressing need to develop an innovation agenda for Southern countries with a 'Southern mindset', while at the same time they continue to heavily rely on a reductionist version of NISs approaches. NISs have become 'a sort of gospel that nobody questions anymore' (Albert and Laberge 2007, p. 230), because it is carried by an established epistemic community (Adler and Haas 1992; Haas 1992). Albert and Laberge (2007) have analysed this for Canada and Quebec (and, more broadly, OECD countries), and we find a similar situation in Latin American countries, including a strong presence of key figures in NISs approaches like Lundvall and Soete's (2002). This helps to explain why it is so difficult to find examples of alternatives to non-NISs-inspired policies in today's Latin American countries that have advanced regimes of STI.

Even with a normative commitment to NISs as a model (which we do not share), one has to consider the risk of its reified use. NISs will then bring about a limited productivity and will not become an integral part of Latin American countries. So already within the NISs epistemic community there must be better attention to the productivity of the NISs approach and the effectivity of STI regimes. 


\section{NEW DIRECTIONS FOR RESEARCH IN NATIONAL INNOVATION SYSTEMS}

Science, technology and policy (STP) studies, not only in Latin America, have internalized NISs to some extent, while the important task is to deconstruct and reconstruct the approach. Such a reconstruction can start by revisiting dependency theory, with the benefit of post-colonial science and technology studies (PCSTS) and world-system analysis (WSA). We will add a brief critical consideration of the focus on economic growth.

The social, political and historical dynamics at play during the developmental, translation and transformation processes of regimes of STI are not just context, but integral to them. Elements get entangled, and stabilized patterns occur (Harding 2008 refers to 'suturing processes'). Our research agenda builds on a PCSTS perspective (see for example Anderson 2002; Anderson and Adams 2008; Harding 2008, 2011). PCSTS have mostly neglected the topic of innovation and the cultural hegemonism it potentially embeds, yet our critique of the reification of NISs is an attempt to start doing so. We share with PCSTS a central commitment to take the standpoint(s) of non-Northern countries and cultures in order to critically re-examine both Northern and Southern scientific and technological traditions and policyoriented approaches.

Hence the critique of the reification of NISs, as we understand it, aims 'to identify, explain, and transform the conceptual and material practices of power of the dominant social institutions, including research disciplines, in ways that benefit those who are least advantaged by such institutions' (Harding 2008). This is not just a way to set the scene for 'progressive STP studies'; it is a way forward for scholarly work with NISs without falling into the trap of immediate reification. Description of 'alternative modernities', and the recognition of hybridities, borderlands and in-between conditions (Anderson 2002, p.643) become important. Under such an analytical approach, there is an increased recognition of the need to critically engage in the 'coloniality of power' (Quijano 2000), especially the way some research disciplines like innovation studies have provided the 'conceptual practices of power' (Smith 1990). In the case of Latin American countries, this would also imply delving into earlier debates engaging with, and critical of, the dominance of Northern institutional models of science and science organization (i.e. Amin's 
proposition to 'delink' Southern sciences from Northern projects and triumphalism; see Amin 1990) in order to investigate the relations between science and technology traditions in the North and the South and 'study up' from the standpoint of non-OECD cultures (Harding 2008, p. 225).

So far, Northern and Southern innovation studies scholars have criticized the Washington Consensus, but it did not succeed in shifting the dominant approaches, including the ones that prevail within NISs. Also, coming in from another angle, there are calls from innovation scholars to move beyond a national focus when dealing with innovation, for example Pietrobelli and Rabellotti (2009, p.214), who note that the most useful definition of innovation systems might not necessarily coincide with national borders ... In recent years it has increasingly been stressed that the innovation system approach needs to be enriched by the international dimension.' Taking all this together, we propose to undertake a WSA (Wallerstein 1974; Chase-Dunn and Hall 1997; Hall 2000; Wallerstein 2006) while dealing with NISs. We find it relevant, since it provides a set of valuable resources that would, among other contributions, respond to Lundvall and Soete's (2002) call to develop an analytical framework that would incorporate the rapid rise in globalization pressures and the corresponding weakness of global governance mechanisms'.

To grasp the full texture of these global reconfigurations we consider that WSA provides an important lens that has been neglected by STP studies. Instead of nation states as the basic unit of social analysis, WSA stresses that world-systems should be the privileged unit of analysis. A world-system broadly refers to a matrix made of various institutions: nation states, interstate systems, corporations, social classes, households, kin, ethnic groups and so on. It relates to the international division of labour, which divides the world into core countries, semi-periphery countries and periphery countries. Recent STIP studies on European countries acknowledge that the international division of labour is an important explanatory factor of evolving patterns of innovation, while it is usually not taken into consideration (see Filippetti and Archibugi 2011, p. 189).

For WSA, international division of labour is of first importance. In the 1970s and 1980s, the simple message was that core countries focus on higher-skill, capital-intensive production, and the rest of the world focuses on low-skill, labour-intensive 
production and extraction of raw materials. In today's multipolar world, big countries like India, China, Brazil or Argentina show internal tensions and a blurring of the international division of labour, for example in the fields of information and communication technologies, media or agricultural biotechnology. Nevertheless, even if some shifting occurs, the earlier pattern of international division of labour is not undermined, and it continues to constantly reinforce the dominance of the core countries, as dependency theorists earlier argued. ${ }^{13}$ So WSA is a reason to scrutinize, in each NISs-related case, how and where power relations are enacted and reinforced. Of course WSA is also at risk of being reified as a simplistic world-system view on hegemony and domination. WSA cannot avoid reducing complexity, but in this view the reduction sometimes goes too far.

We consider the world-system as sustaining inner dynamics in its national-international relations. Individual states can gain or lose the core status over time. Importantly, the coreperiphery dichotomy is a relational concept (e.g. Wallerstein 2004, 2006). At a first glance, one might see analytical frictions between WSA and NISs. But the 'eclipse of the nation state' argument is misleading: nations do exist, and they craft policies and institutions that are important nationally. At the same time, as we noted, innovation institutions, frameworks and policies do extend beyond and across nations. Instead of frictions, we see loci of complex interplays and national-international relationships we aim at unfolding.

Globalization - which is not a new phenomenon (see for example Wallerstein 1974) - does not decrease the importance of the nation state; on the contrary, it makes national action and policies more necessary, but also more difficult (Archibugi and Michie 1997, p.131). Value chains have become more international, and the local conditions are most often unfavourable for Southern countries, as numerous examples show in Latin America with mining, computers or pulp mills. As Lastres and Cassiolato (2002, p.5) acknowledge, the evolution of a national (or regional) economic system depends, to a large extent, on its place in the hierarchy and power structure of the world capitalist system.

The question of dependency is not just about power; it also sheds light on what one could call the directionality of NISs approaches. When looking at non-OECD countries, we think in particular of what could be termed 'developmentality', that is, 
when a narrow conception of development is assigned to those countries as an ultimate finality. As we pointed out previously, NISs are built around the idea that technological change will be advocated to develop economies by means of wealth generation, and GDP is used as a criterion to assess and compare the performances of each country. ${ }^{14}$ While this approach has been critiqued since the late 1950s by Latin American intellectuals, worldsystem analysts and dependency theorists, it is still dominant: 'the concept of development was constructed and continues to be used in political economy based on an implicit standard of Western economic growth, measured by the yardstick of industrialization and urbanization ... Modernity consists in embracing industrial development and the growth of market' (Debal 2009, p. 42).

In Latin American countries, each time the 'relevance' of NISs to Latin American countries was addressed (Vasen 2011), or whenever adopting NISs as the preferred way out of poverty and social inequalities emerged, most of the time resulting from the implication of international institutions (Arocena and Sutz 2000, 2003), this debate about developmentality surfaced, but the emphasis on wealth generation continued. New approaches are necessary to go beyond the mere pursuit of economic growth. There are more dimensions to development, and the notion of 'growth' can be deflated. ${ }^{15}$ A better way of phrasing this is the need for analytical differentiation among different kinds of growth in terms of their social relevance (cf. Jackson 2009). Considering alternatives to growth should not become a new dogma, a counter-ideology to growth (Latouche 2007), but should rather address all kinds of growth as desirable in their own right when they will result in societal benefits (Latouche 2004; Fournier 2008). Such analyses then link up with the setting of the political agenda of a country, and this indicates another complexity that has to be taken up in a renewed NISs approach.

One issue that has then to be addressed is that the science and technology (S\&T) policies backgrounding economic growth carry the risk of forgoing opportunities to reduce social inequalities, or would limit Southern countries' sovereignty over their own natural resources. ${ }^{16}$ Development of non-OECD countries and their economies must include improved wealth generation and distribution. Our point here rather relates to the actual ability, for Latin American countries, to set the political agenda as they see fit for their societies. The NISs approach can be 
mobilized to support and inform this, but has to be less reductionist and include the complexities.

\section{CONCLUSION}

In this chapter, we critically engaged with the widespread and influential approach of NISs, going beyond the 'charmed circle' of OECD countries. We observed a tendency to reify a simple version of NISs approaches, which leads to serious shortcomings, conceptually and practically, thus leading to somehow dancing the innovation policy dance but without listening to its inner music. First, NISs approaches tend not to take the broader socio-political landscape and the global context sufficiently into account. Second, because of the neoliberal commitments that go with the actual use of NISs, it tends to reproduce the balance of powers between richer and poorer countries, even while it pursues the objective of socio-economic development. Third, NISs approaches advocate (technological) innovation for change in society, but with a reductionist focus on GDP generation and the pursuit of economic growth in the framework of international economic benchmarking. The reduction of complexity that such a concept brings has gone too far.

However, NISs approaches could benefit from being more encompassing in terms of a greater diversity and complexity in their matrices, henceforth engaging in a systemic perspective. This has been recognized, but somehow the reduced and reified approach continues. We showed how the historical trajectory of the STI regimes in Latin America came to fall under NISs' spell. And, while numerous Southern scholars urge the pressing need to develop an innovation agenda for Southern countries with a 'Southern framework of thought', they continue to rely heavily on a reductionist version of the NISs approach that prevents such a 'Southern perspective' from fully emerging. If the conditions were met for such a perspective to emerge, then one could argue that eventually it could lead to a genuine innovation policy dance (Kuhlmann et al. 2010) which could lead to some contextual harmonics.

This critical move is not new and deserves second thoughts about what comes next. A push to recontextualize overarching models is increasingly gaining traction. In our view, STI policies should not only adjust the 'signal' they receive from the field 
that indicates that a policy is successfully implemented or not. Rather, they should broaden their scope for good and include more analytical perspectives, which deepen and complicate the understanding of concrete situations and contexts. It is a matter of not reproducing some kind of ready-made solutions which only reproduce what they might very well be criticizing, for instance the lack of contextual texture of current international policies.

For this reason, we suggested a threefold analytical deepening of STI policies in context, all with the aim of gaining an improved understanding of actual STI regimes. There certainly are practical or political reasons to explore ways to overcome the conceptual limitations of NISs approaches, as practised in present STP studies. While this approach remains important, and may still be relevant in the context of Northern countries, outside this 'charmed circle' it would benefit from a postcolonial perspective. This must be part of a broader analysis, because dependency relations and power strategies and shifts are not limited to former colonies any more. This is where a WSA approach, nuanced so as to include the continuing role of nation states, can contribute. NISs are opened up and studied as part of world-system dynamics, but in the same movement this can inform new pathways in national STI regimes and new S\&T policy approaches. This will lead to including a 'postdevelopmentality' approach, transcending the narrow focus on GDP and economic growth.

The world is changing fast, and it seems that a renewed version of the dependency theory is in order. Constant shifts are happening which urge us to render approaches such as NISs more adequate in the face of fast contextual evolutions. ${ }^{17}$ Given that NISs expanded at a rapid pace and disseminated impressively in Latin America for almost two decades, it cannot just be thrown out. But the pitfall of reification has to be avoided. Demonstrating openness to situated socio-political contexts and local realities, while taking global developments into account, will strengthen NISs approaches and their articulations to actual policies. An additional benefit might well be that such a broader approach can be a model for analysing NISs in OECD countries as well, in the emerging new world order. 


\section{ACKNOWLEDGEMENTS}

\section{The authors gratefully acknowledge Arie Rip and Daniel} Sarewitz's very helpful suggestions and comments on earlier versions of this chapter, as well as the anonymous reviewers who provided relevant comments which helped us to reinforce the thrust of the chapter. This chapter was supported by the Fonds National de la Recherche Scientifique, F.R.S.-FNRS.

\section{NOTES}

1. This chapter builds heavily on a previous version of our work, published in Delvenne and Thoreau (2012). We wish to thank the reviewers of this version who forced us to further some of our arguments and to alleviate a couple of blind spots from other disciplinary perspectives.

2. For this reason, we chose to refer to 'NISs' in the plural form instead of 'NIS' as if it were a unified, monolithic concept.

3. Authors like Jensen et al. (2007) also point at other forms of knowledge and modes of innovation, like the doing, using and interacting (DUI) concept, describing innovation mainly as a set of incremental changes in products and processes based on experiences and embodied competences.

4. We address these issues from a macro- and political-economic perspective, which we believe is the first step for rethinking the powerful theoretical concepts of STIP studies in order for them to be retaken up by policy analysts and innovation actors. To this extent, if taken up by such actors, our contribution may foster very practical consequences at the meso and micro levels - it is not for us to tell or guarantee.

5. One of our reviewers argued that, 'because innovation systems literature were coming from an economic/management discipline, they did not include a political or development dimension. It might be true that NIS got "politicized/compromised" in Latin America, but its foundations by Freeman, Lundvall, Edquist - to name but a few - were not.' We strongly disagree with the reviewer on this point. In our opinion, to the contrary, NISs has politics, either in OECD countries or elsewhere, as it aligns with dominant STI modes of knowledge making. Even when they would not endorse it, NISs promoters and the knowledge they produce are always and immediately entangled in stories and actions that carry forth specific political configurations. This disagreement seems unconcealable, since it finds its roots in the development of neoclassical paradigms of economy, which envision economy as separated from its social fabric. Following Boltanski and Chiapello (2007) or Mirowski and Sent (2002), we consider that economics are not and cannot constitute an autonomous sphere insulated from other social activities, hence being necessarily political.

6. For example, Viotti (2002, p.656) points out the bias of NISs studies towards 'innovation', which has a secondary role or possibly no role at all in the process of Southern countries' technical change.

7. In his view, 'The main striking difference with respect to the recent evolution of India's NIS is that their economic reforms were not as influenced by the Washington Consensus's recommendations as was the case in Brazil. Therefore, in the Indian experience the introduction of liberalizing reforms, aside from breaking with strongly protectionist practices, did not imply significant discontinuity with respect to industrial and technological policies that had been adopted in the country before the early 1990s' (Nassif 2007, p.20) 


\section{Research handbook on innovation governance for emerging economies}

8. We refer to the 'voyages of discovery' carried out on behalf of the European empires that later permitted the tremendous expansion of Northern sciences, causing the massive destruction of local and indigenous people and knowledge. Our suggestion of moving away from the OECD suggests that there is a need to rediscover Latin America with fresh eyes, and not immediately fall into the normative trap of reifying NISs. New insights of innovation (and innovation concepts) like development alternatives that flourished in other extra-OECD contexts, as in China, Russia, South Africa or India, may offer further opportunities for unfolding the same critique of reification. However, those fall out of the scope of the present chapter, which has Latin America as its main focus.

9. Our attempt to look at current patterns of change in Latin American STI regimes resonates with the concept of an 'endogenous future' (Rip and te Kulve 2008, p.51): the idea that further developments are predicated on the pattern of the present situation, which shows choices, contingencies, possibilities and emerging irreversibilities.

10. However, according to Vidal and Marí (2002), both international institutions had the same philosophy. UNESCO was promoting a pure science based on academic excellence, while OAS instituted a more 'hybrid model' that combined a support of basic scientific infrastructure with the promotion of technological development.

11. Dependency theory was certainly not made of one single current of thought, however. Vernengo rightly points at the two different coexisting traditions in dependency theory, while he underscores that both groups would agree that at the core of the dependency relationship between centre and periphery lies the inability of the periphery to develop an autonomous and dynamic process of technological innovation (2006, p.552).

12. See the RICYT website: http:/ / www.ricyt.org/ (last accessed 31 March 2012).

13. Wallerstein explicitly acknowledges dependency theory's influence (both its concepts and its diagnosis) as one of the origins of WSA (2008, pp.34-35).

14. For example in the Handbook of Innovation Systems and Developing Countries, edited by Lundvall et al. (2009). See also Metcalfe and Ramlogan (2008).

15. One example of such an approach, particularly visible in Belgium and in France, is the deflation of wealth generation in the so-called 'degrowth' conferences and the $R \& D$ research consortium for research and degrowth. See http://www.degrowth. eu/ (last accessed 31 March 2012).

16. Herrera and his collaborators were already concerned about these risks when they opposed the Club of Rome's project 'The Limits to Growth' and suggested a counter-global model, originating from Latin America (see Herrera et al. 2004).

17. This is true not only for non-OECD countries. Based on past success stories, NISs have also been used as a blueprint for economic development in less dynamic OECD regions. The argument of this chapter remains equally valid: the contextual realities in any country - developed and developing alike - are just too complex to use NISs as a reified blueprint.

\section{REFERENCES}

Adler, E. and P. Haas (1992), 'Conclusion: Epistemic Communities, World Order and the Creation of a Reflective Research Program', International Organization, 46 (1), 367-390.

Albert, M. and S. Laberge (2007), 'The Legitimation and Dissemination Processes of the Innovation System Approach: The Case of the Canadian and Québec Science and Technology Policy', Science, Technology and Human Values, 32 (2), 221-249.

Albornoz, M. and A. Gordon (2011), 'La política de ciencia y tecnología en Argentina desde la recuperación de la democracia (1983-2009)', in M. Albornoz and J. Sebastián 
(eds), Trayectorias de las políticas científicas y universitarias de Argentina y España, Madrid, Spain: CSIC, pp.1-46.

Amin, S. (1990), Delinking: Towards a Polycentric World, New York: Zed Books.

Anderson, W. (2002), 'Postcolonial Technoscience', Social Studies of Science, 32, 643-658.

Anderson, W. and V. Adams (2008), 'Pramoedya's Chickens: Postcolonial Studies of Technoscience', in E.J. Hackett, O. Amsterdamska, M. Lynch and J. Wacjman (eds), Handbook of Science and Technology Studies, 3rd edn, Cambridge, MA, USA: MIT Press, pp.181-204.

Archibugi, D. and J. Michie (1997), 'Technological Globalization or National Systems of Innovation?', Futures, 29 (2), 121-137.

Arocena, R. and J. Sutz (2000), 'Looking at National Systems of Innovation from the South', Industry and Innovation, 7 (1), 55-75.

Arocena, R. and J. Sutz (2003), 'Inequality and Innovation as Seen from the South', Technology in Society, 25 (2), 171-182.

Boltanski, L. and E. Chiapello (2007), The New Spirit of Capitalism, London: Verso.

Bruno, I. (2009), "The "Indefinite Discipline" of Competitiveness Benchmarking as a Neoliberal Technology of Government', Minerva: A Review of Science, Learning and Policy, 47 (3), 261-280.

Chase-Dunn, C. and T. Hall (1997), Rise and Demise: Comparing World-systems, Boulder, CO, USA: Westview Press.

Debal, D. (2009), Developmentality: Constructing Inclusive Freedom and Sustainability, London: Earthscan.

Delvenne, P. (2011), Science, technologie et innovation sur le chemin de la réflexivité: Enjeux et dynamiques du Technology Assessment parlementaire, Louvain-la-Neuve, Belgium: Academia l'Harmattan.

Delvenne, P. and F. Thoreau (2012), 'Beyond the "Charmed Circle" of OECD: New Directions for Studies of National Innovation Systems', Minerva: A Review of Science, Learning and Policy, 50 (2), 205-219.

Delvenne, P. and F. Vasen (2013), 'Lo que los Sistemas Nacionales de Innovación no miran: Una crítica constructiva de las políticas de ciencia y tecnología a partir del "modelo de la soja transgénica"', in F. T. Molina and A. M. Vara (eds), Riesgo, política y alternativas tecnológicas: Entre la regulación y la discusión pública, Buenos Aires, Argentina: Prometeo, pp. 210-242.

Edquist, C. (2004a), 'Systems of Innovation: Perspectives and Challenges', in J. Fagerberg, D.C. Mowery and R.R. Nelson (eds), The Oxford Handbook of Innovation, Oxford, UK: Oxford University Press, pp.181-208.

Edquist, C. (2004b), 'Reflections on the Systems of Innovation Approach', Science and Public Policy, 31 (6), 485-489.

Edquist, C. and B.-Â. Lundvall (1993), 'Comparing the Danish and Swedish Systems of Innovations', in R.R. Nelson (ed.), National Innovation Systems, New York: Oxford University Press, pp. 265-298.

Fagerberg, J. and K. Sapprasert (2011), 'National Innovation Systems: The Emergence of a New Approach', Science and Public Policy, 11, 669-679.

Fagerberg, J. and B. Verspagen (2009), 'Innovation Studies - the Emerging Structure of a New Scientific Field', Research Policy, 38, 218-233.

Filippetti, A. and D. Archibugi (2011), 'Innovations in Time of Crisis: National Systems of Innovation, Structure and Demand', Research Policy, 40, 179-192.

Fournier, V. (2008), 'Escaping from the Economy: The Politics of Degrowth', International Journal of Sociology and Social Policy, 28 (11-12), 528-545.

Freeman, C. (1987), Technology Policy and Economic Performance: Lessons from Japan, London: Pinter.

Freeman, C. (1995), "The "National System of Innovation" in Historical Perspective', Cambridge Journal of Economics, 19, 5-24.

Freeman, C. (2002), 'Continental, National and Sub-national Innovation Systems Complementarity and Economic Growth', Research Policy, 31, 191-211. 


\section{Research handbook on innovation governance for emerging economies}

Garud, R. and P. Karnoe (2010), 'Path Dependence and Creation: Alternative Theoretical and Methodological Perspectives on Strategy, Innovation and Entrepreneurship', Journal of Management Studies, 47 (4), 733-735.

Godin, B. (2009), 'National Innovation System: The System Approach in Historical Perspective', Science, Technology and Human Values, 34 (4), 476-501.

Haas, P. (1992), 'Introduction: Epistemic Communities and International Policy Coordination', International Organization, 46 (1), 1-35.

Hall, T. (2000), A World-systems Reader: New Perspectives on Gender, Urbanism, Cultures, Indigenous Peoples and Ecology, London: Rowman \& Littlefield.

Harding, S. (2008), Sciences from Below: Feminism, Postcolonialities, and Modernities, Durham, NC, USA: Duke University Press.

Harding, Sandra (ed.) (2011), The Postcolonial Science and Technology Studies Reader, Durham, NC, USA: Duke University Press.

Herrera, A. (1971), Ciencia y política en América Latina, Mexico City: Siglo XXI.

Herrera, A., H. Scolnick, G. Chichilnisky, G. Gallopin, J. Hardoy, D. Mosovich, E. Oteiza, G. de Romero Brest, C. Suárez and L. Talavera (eds) (2004), ¿Catástrofe o nueva sociedad? Modelo Mundial Latinoamericano 30 años después, Ottawa, Canada: International Development Research Centre.

Jackson, T. (2009), Prosperity without Growth: Economics for a Finite Planet, London: Earthscan.

Jensen, M.B., B. Johnson, E. Lorenz and B.-Å. Lundvall (2007), ‘Forms of Knowledge and Modes of Innovation', Research Policy, 36, 680-693.

Kuhlmann, S. (2001), 'Governance of Innovation Policy in Europe: Three Scenarios', Research Policy, 30 (6), 953-976.

Kuhlmann, S. (2007), 'Governance of Innovation: Practice, Policy and Theory as Dancing Partners', Address delivered upon the acceptance of the Chair of Foundations of Science, Technology and Society, Faculty of Management and Governance, University of Twente, the Netherlands.

Kuhlmann, S., P. Shapira and R. Smits (2010), 'Introduction: A Systemic Perspective: The Innovation Policy Dance', in R. Smits, S. Kuhlmann and P. Shapira (eds), The Theory and Practice of Innovation Policy: An International Research Handbook, Cheltenham, UK and Northampton, MA, USA: Edward Elgar, pp.1-22.

Lastres, H.M.M. and J.E. Cassiolato (2002), 'Systems of Innovation and Development from a South American Perspective: A Contribution to Globelics', First Globelics Workshop, Aalborg University, 4-6 November.

Latouche, S. (2004), Survivre au développement: De la décolonisation de l'imaginaire économique à la construction d'une société alternative, Paris: Mille et une Nuits.

Latouche, S. (2007), Petit traité de la décroissance sereine, Paris: Mille et une Nuits.

Lundvall, B.-A. (1992), National Systems of Innovation, London: Pinter.

Lundvall, B.-Á. (2005), 'National Innovation Systems - Analytical Concept and Development Tool', Working paper presented at the DRUID Tenth Anniversary Summer Conference on the Dynamics of Industry and Innovation: Organizations, Networks and Systems, Copenhagen, Denmark, accessed at http://www.druid.dk/ conferences/Summer2005/Papers/Lundvall.pdf.

Lundvall, B.-Å. and L. Soete (2002), 'Background Paper about Globelics', accessed at http://www.globelics.org/.

Lundvall, B.-A., K.J. Joseph, C. Chaminade and J. Vang (eds) (2009), Handbook of Innovation Systems and Developing Countries: Building Domestic Capabilities in a Global Setting, Cheltenham, UK and Northampton, MA, USA: Edward Elgar.

Marques, R. and C.N. Gonçalves (2007), 'The Brazilian System of Innovation in Biotechnology: A Preliminary Study', Journal of Technology Management and Innovation, $2(1), 55-63$.

Melo, A. (2001), The Innovation Systems of Latin America and the Caribbean, Working Paper no. 460, Washington, DC: Inter-American Development Bank.

Metcalfe, S. and R. Ramlogan (2008), 'Innovation Systems and the Competitive 
Process in Developing Economies', Quarterly Review of Economics and Finance, 48 (2), 433-446.

Mirowski, P. and E. Sent (2002), Science Bought and Sold: Essays in the Economics of Science, Chicago, IL, USA: Chicago University Press.

Nassif, A. (2007), National Innovation System and Macroeconomic Policies: Brazil and India in Comparative Perspective, UN Conference on Trade and Development Discussion Paper no. 184, accessed at http://www.unctad.org/en/docs/osgdp20073_en.pdf.

Nelson, R. (ed.) (1993), National Innovation Systems: A Comparative Study, Oxford, UK: Oxford University Press.

Niosi, J. (2002), 'National Systems of Innovation are "x-efficient" (and x-effective): Why Some Are Slow Learners', Research Policy, 31, 291-302.

Pellegrini, P. (2011), 'Agriculture transgénique: Modes de production et utilisation de la connaissance scientifique: Science, Etat et Industrie dans les cultures transgéniques en Argentine', Ph.D. thesis, Universidad de Quilmes, Buenos Aires, Argentina.

Pietrobelli, C. and R. Rabellotti (2009), 'The Global Dimension of Innovation Systems: Linking Innovation Systems and Global Value Chains', in B.- $\AA$. Lundvall, K.J. Joseph, C. Chaminade and J. Vang (eds), Handbook of Innovation Systems and Developing Countries: Building Domestic Capabilities in a Global Setting, Cheltenham, UK and Northampton, MA, USA: Edward Elgar, pp. 214-238.

Quijano, A. (2000), 'Coloniality of Power and Eurocentrism in Latin America', International Sociology, 15 (2), 215-232.

Rip, A. (1992), 'Science and Technology as Dancing Partners', in P. Kroes and M. Bakker (eds), Technological Development and Science in the Industrial Age, Amsterdam, the Netherlands: Kluwer, pp. 231-270.

Rip, A. and H. te Kulve (2008), 'Constructive Technology Assessment and Sociotechnical Scenarios', in E. Fisher, C. Selin and J.M. Wetmore (eds), The Yearbook of Nanotechnology in Society, Vol. 1: Presenting Futures, Dordrecht, the Netherlands: Springer, pp.49-70.

Roninger, L., J. Green and P. Yankelevitch (eds) (2012), Exile and the Politics of Exclusion in the Americas, Eastbourne, UK: Sussex Academic Press.

Sábato, J. (2004 [1979]), Ensayos en campera, Bernal, Argentina: Universidad Nacional de Quilmes.

Sharif, N. (2006), 'Emergence and Development of the National Innovation Systems Concept', Research Policy, 35 (5), 745-766.

Shinn, T. (2002), 'The Triple Helix and New Production of Knowledge: Pre-packaged Thinking on Science and Technology', Social Studies of Science, 32 (4), 599-614.

Smith, D.E. (1990), The Conceptual Practices of Power: A Feminist Sociology of Knowledge, Boston, MA, USA: Northeastern.

Sutz, J. (2003), 'Inequality and University Research Agendas in Latin America', Science, Technology and Human Values, 28 (1), 58-62.

Varsafsky, O. (1972), Hacia una política científica nacional, Buenos Aires, Argentina: Periferia.

Vasen, F. (2011), 'Los sentidos de la relevancia en la política científica', Revista Iberoamericana de Ciencia, Tecnología y Sociedad, 19 (7), 1-31.

Vernengo, M. (2006), 'Technology, Finance, and Dependency: Latin American Radical Political Economy in Retrospect', Review of Radical Political Economics, 38 (4), 551-568.

Vidal, C.M. and M. Marí (2002), 'La Escuela Latinoamericana de Pensamiento en Ciencia, Tecnología y Desarrollo: Notas de un proyecto de investigación', Revista Iberoamericana de Ciencia, Tecnología, Sociedad e Innovación, 4, 1-19.

Viotti, E.B. (2002), 'National Learning Systems: A New Approach on Technological Change in Late Industrializing Economies and Evidences from the Cases of Brazil and South Korea', Technological Forecasting and Social Change, 69 (7), 653-680.

Wallerstein, I. (1974), The Modern World-system, Vol. 1: Capitalist Agriculture and the Origins of the European World-economy in the Sixteenth Century, Cambridge, UK: Cambridge University Press. 


\section{Research handbook on innovation governance for emerging economies}

Wallerstein, I. (2004), The Uncertainties of Knowledge, Philadelphia, PA, USA: Temple University Press.

Wallerstein, I. (2006), Comprendre le monde: Introduction à l'analyse des systèmes-monde, Paris: La Découverte. 